\title{
Railroad Concentration, Market Shares, and Rates
}

\section{Summary}

Since the passage of the Staggers Act in 1980, many railroads have merged. The market share of Class I railroads has increased since then, while the number of Class I railroads has fallen to only seven. Through railroad mergers, rail-torail competition has been reduced, railroad market power has increased, and rail costs have fallen by over half in real terms. Over much of this period, most of these reduced costs were passed on to shippers as savings through lower rates. Since 2004, however, average rail rates per ton-mile for all commodities have climbed 36 percent, negating some of the savings over the period. Although some of these real rail rate increases have contributed to record rail profitability and capital investment, most of the rate increases are the result of increased railroad costs; real rail costs, adjusted for productivity, increased 29 percent during the same period.

Although deregulation of railroads in 1980 produced more than 550 regional and local railroads throughout America, the 7 Class I railroads originated well over half the grain and oilseed shipments in 2011.

\section{Introduction}

For many years, railroads have been merging in order to increase efficiency and develop financially stable rail businesses large enough to compete with other modes of transportation, mostly trucks and barges. Following the passage of the Staggers Rail Act of $1980,{ }^{1}$ the pace of merger activity increased as railroads strove to reduce costs, increase efficiency, and increase the area they served, while eliminating unnecessary lines and enhancing their market power.

\section{Railroad Mergers}

Since the 1920s, railroads have undergone many mergers. During the 1960 s and 1970 s, many of the mergers combined financially weak railroads with stronger firms in hopes of developing financially stable businesses large enough to compete effectively with other transportation modes. After the Staggers Rail Act of 1980, the pace of merger activity picked up as railroads strove to increase geographic range, eliminate duplicate lines, reduce costs, and gain increased market power. In 1980, there were 33 Class I railroads in the United States; today there are only 7. 
When the Staggers Act was enacted, many shippers did not foresee the extent of the loss of rail-to-rail competition because of mergers and the resulting increase in market power of the railroads. Economists, however, anticipated the rationalization of the rail network because the regulated railroad industry was characterized by overcapacity, so a reduction in excess capacity was a logical and expected result of deregulation. The concentration of increased tonnage on fewer track miles has enabled railroads to reap the benefits from economies of density, under which firms gain cost savings from the density of traffic within their network. Studies have shown that rail rates have fallen 60 percent in real terms-and that most of these savings have been passed on to shippers. ${ }^{2}$

Today there are two major duopolies for grain transportation-BNSF Railway and Union Pacific Railroad serve the Western United States, and CSX Transportation and Norfolk Southern serve the East. In addition to these four megarailroads, three smaller Class I railroads-Canadian National Railway, Canadian Pacific, and Kansas City Southern Railway - serve the central portion of the Nation. In 2011, in addition to these Class I railroads, there were also 21 regional and 539 local railroads. (Before the Staggers Act, there were about 220 regional and local railroads.) $)^{3}$ See table 1 for a summary of the Class I railroad mergers.

Table 1. Railroad Mergers

\begin{tabular}{|l|l|}
\multicolumn{1}{|c|}{ Predecessor Railroads } & \multicolumn{1}{|c|}{ Merged Railroad } \\
\hline $\begin{array}{l}\text { Burlington Northern } \\
\text { Atchison, Topeka, \& Santa Fe }\end{array}$ & Burlington Northern Santa Fe (BNSF) \\
\hline $\begin{array}{l}\text { Chicago \& Northwestern } \\
\text { Missouri Pacific } \\
\text { Southern Pacific } \\
\text { Union Pacific }\end{array}$ & Union Pacific \\
\hline Illinois Central Gulf & Canadian National (U.S.) \\
\hline $\begin{array}{l}\text { Conrail (58 percent) } \\
\text { Norfolk \& Western } \\
\text { Southern }\end{array}$ & Norfolk Southern \\
\hline $\begin{array}{l}\text { Conrail (42 percent) } \\
\text { Louisville \& Nashville }\end{array}$ & CSX Transportation \\
\hline $\begin{array}{l}\text { Milwaukee } \\
\text { Soo }\end{array}$ & Canadian Pacific (U.S.) \\
\hline
\end{tabular}

\section{Market Concentration and Share}

The top four Class I railroads originated 86 percent of grain and oilseed traffic in 2011, compared to only 53 percent in 1980 (figs. 1 and 2). In addition, the market share of the current railroads has changed from that of their predecessors. The Burlington Northern and the Atchison, Topeka \& Santa Fe, which combined to form Burlington Northern Santa Fe (BNSF), together accounted for only 30 percent of grain and oilseeds originations in 1980. By 2011, the BNSF had 47 percent of the market. This market share growth contrasts with the 31 percent held by Chicago \& Northwestern, Union Pacific, and Missouri Pacific in 1980 that combined into the Union Pacific (UP), which has decreased to only 19 percent in 2011.

2 Surface Transportation Board, Study of Railroad Rates: 1985-2007, January 2009. <http://www.stb.dot.gov/stb/industry/1985-2007RailroadRateStudy.pdf> (PDF)

3 "Regional and Short Line Railroads in the United States," Transportation Quarterly, Fall 2002.

Web. <http://strategicrail.com/wp-content/uploads/2013/04/Regional-and-Short-Line-RRs-in-the-US-Strategic-Rail-Finance.pdf> (PDF) 
Figure 1. Railroad Grain Origination Market Share, 1980

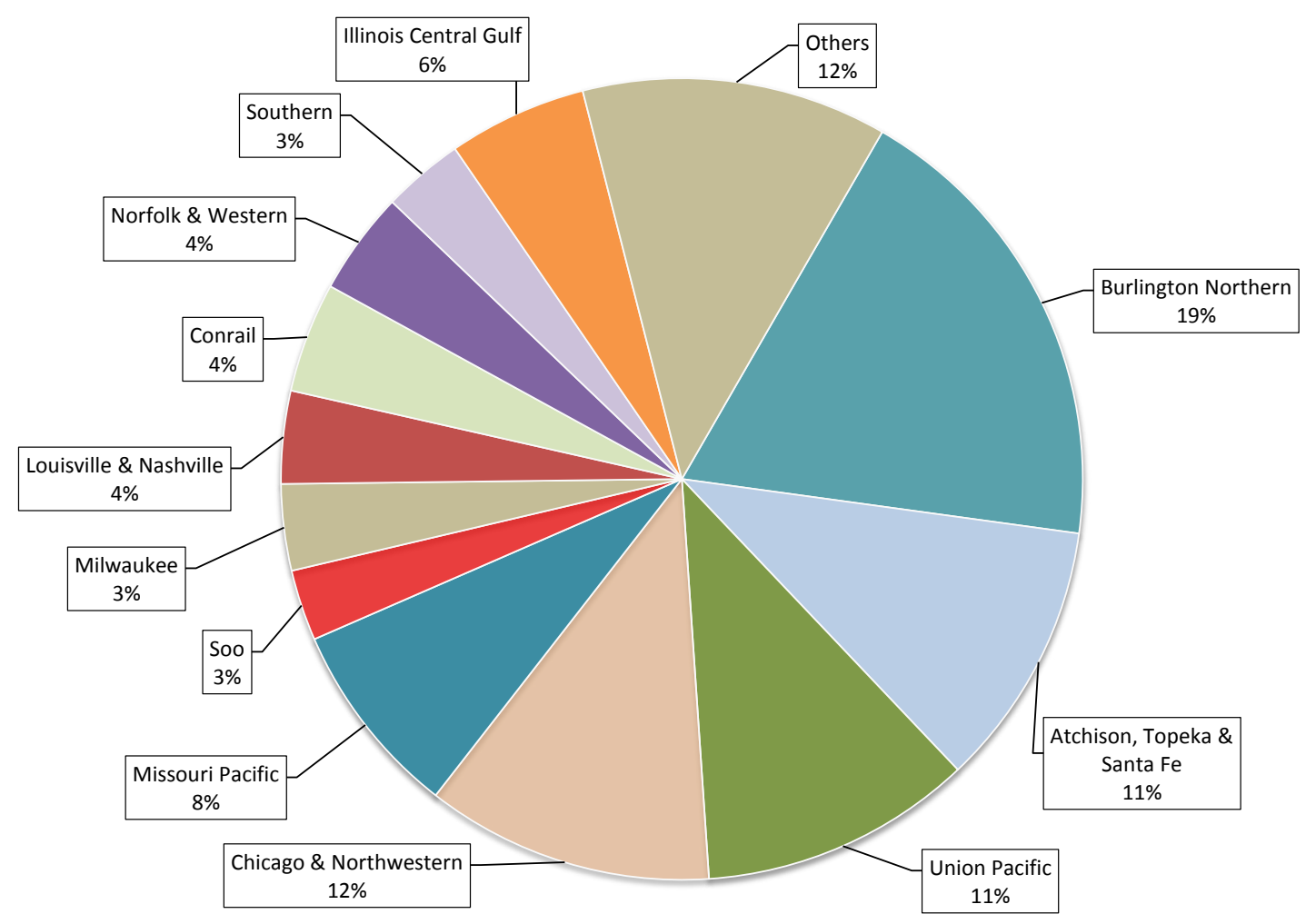

Source: Association of American Railroads

Figure 2. Railroad Grain Origination Market Share, 2011

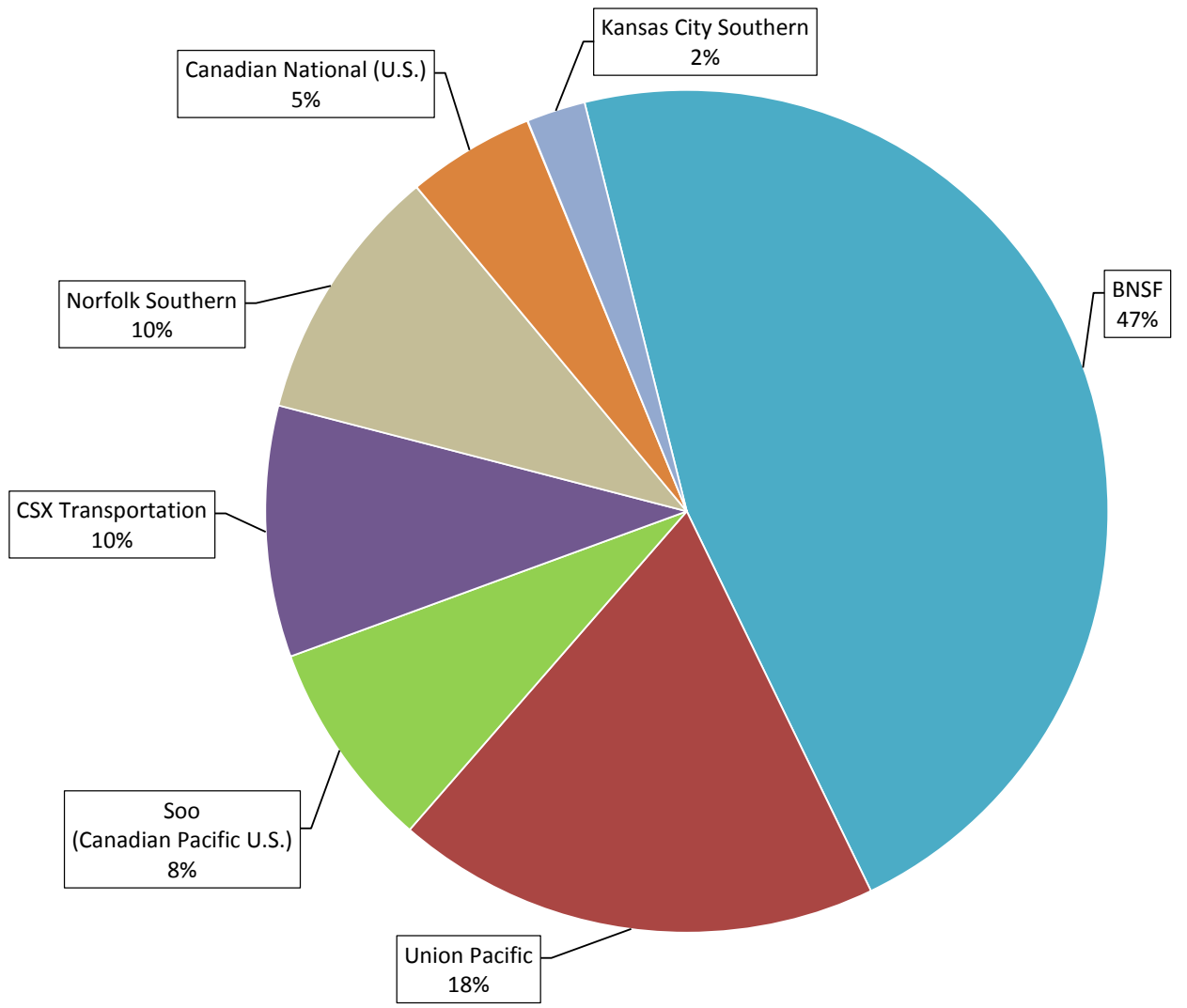

Source: Association of American Railroads 
Railroad concentration and market share are even higher for specific commodities. For instance, the top four Class I railroads transported 96 percent of wheat in 2011 compared to 80 percent in 19944 (see figs. 3 and 4). Over that time, the consolidation was unevenly distributed between the railroads. The market share for BNSF remained the same in comparison to its predecessors - 55 percent in 2011 compared to 55 percent in 1994. The UP market share decreased over the same timeframe; it had only 21 percent in 2011 compared to the 29 percent of its predecessors in 1994 . The Soo (Canadian Pacific U.S.) market share increased to 12 percent in 2011 from only 4 percent in 1994, while the CSX market share increased to 8 percent compared to only 4 percent for its predecessors.

The level of rail-to-rail competition in agriculture should not be viewed as a function of the market concentration of railroads in the Nation as a whole. Instead, it is a function of the quality and effectiveness of competitive options in particular markets. Regional markets are especially important when reviewing agricultural transportation as compared with other products because farming can only happen in certain regions, most of them far away from cost-effective inter-modal competition. Railroads compete not only with other railroads, but also with other modes of transportation.

Using a Herfindahl-Hirschman analysis of rail-to-rail competition applied to crop reporting districts, the U.S. Department of Agriculture (USDA) and the U.S. Department of Transportation (DOT) found that the level of railto-rail competition for grains and oilseeds decreased significantly between 1992 and 2007.5 Almost 75 percent of agricultural areas lost rail competition from 1992 to 2007, and the areas in which a railroad had a monopoly in transporting grain and oilseeds increased from 10 percent to 15 percent. At the same time, the revenue-to-variablecost ratio, a measure of railroad profitability, increased in 83 percent of those areas.

Figure 3. Railroad Wheat Origination Market Share, 1994

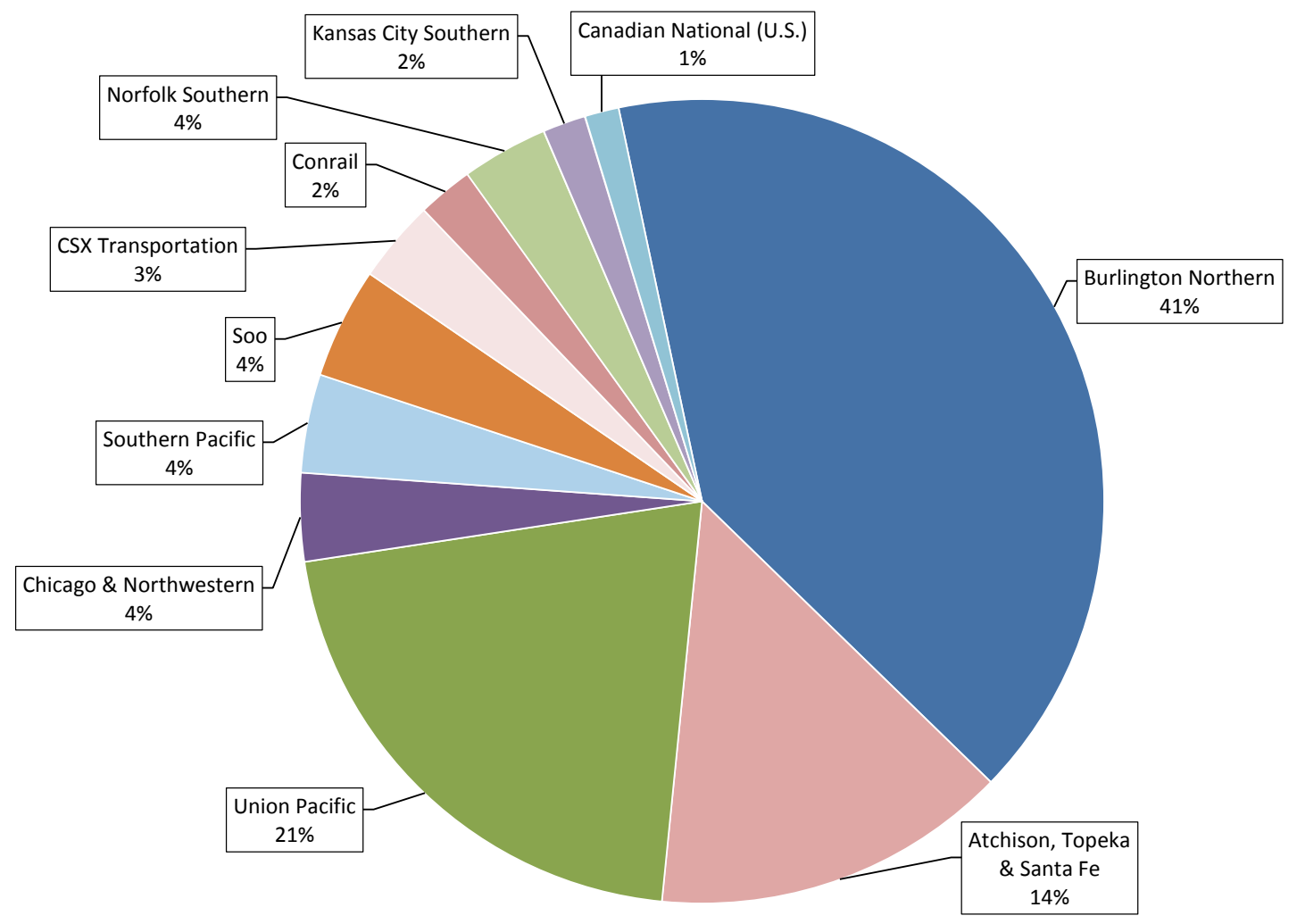

Source: Association of American Railroads

4 Data for wheat is only available after 1994.

5 U.S. Department of Agriculture and U.S. Department of Transportation, Study of Rural Transportation Issues, April 2010. Chap. 6, $217-221$. $<$ http://dx.doi.org/10.9752/TS041.04-2010> 
Figure 4. Railroad Wheat Origination Market Share, 2011

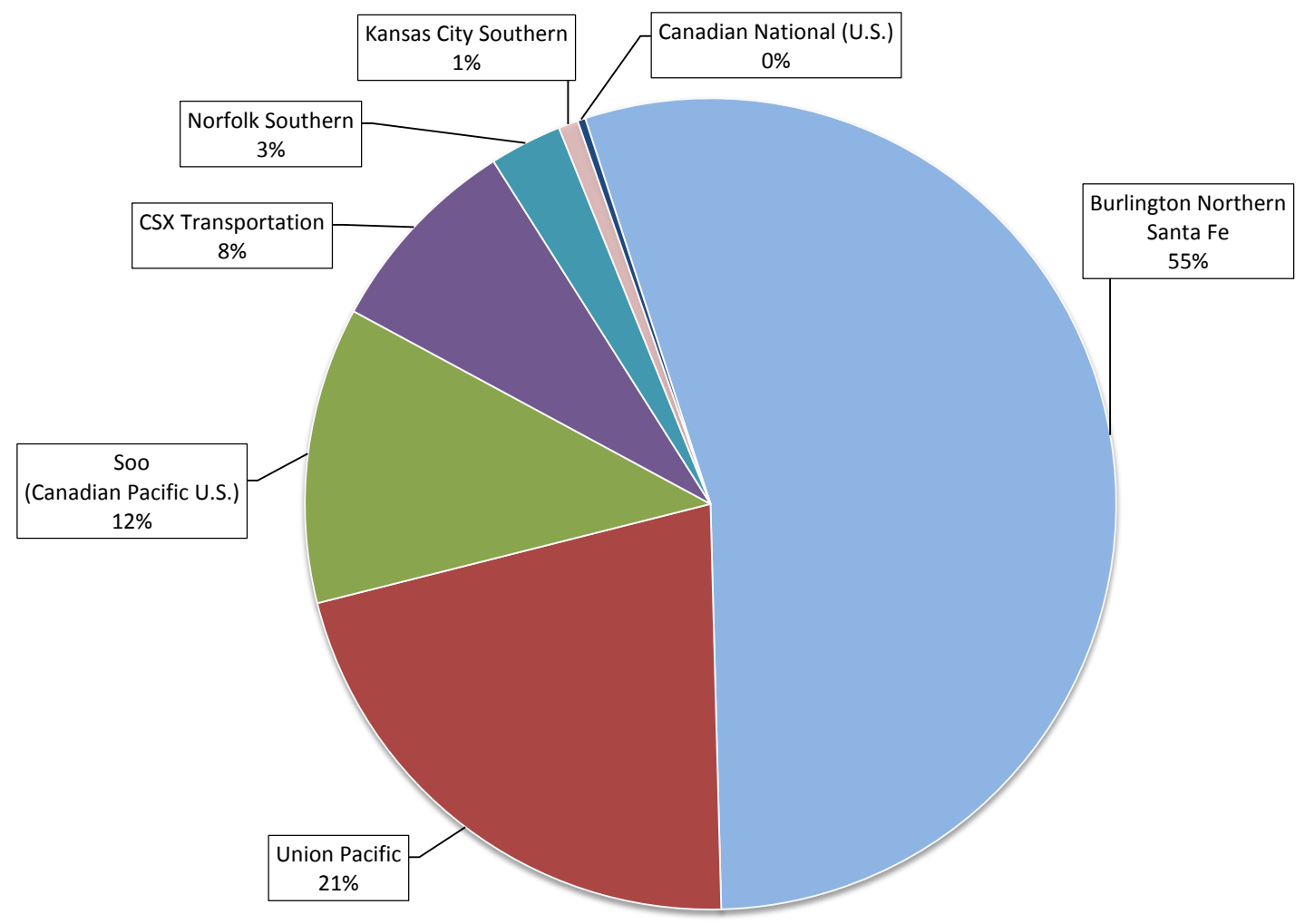

Source: Association of American Railroads

\section{Rail Rates}

Railroad mergers have resulted in reduced rail-to-rail competition and increased railroad market power. From 1980 until 2004, railroads passed some of their reduced costs on to shippers through lower rail tariff rates. ${ }^{6}$ The index of rail rates decreased from 100 in 1985 to 56.8 in 2004, a decrease of 43.2 percent in real (inflation adjusted) rail rates (see fig. 5). Rail capacity constraints first appeared in 2004, resulting in increased rail rates through 2007. The rail rate index increased to 65.5 in 2007, an increase of 15 percent in real rail rates in just 3 years. The Christensen report concluded that these rate increases were due mainly to cost increases rather than market power. ${ }^{7}$

Even though a recession started in December 2007, railroads continued to raise rail rates, partly to support record railroad capital investments and higher costs. Average real rail rates per ton-mile for all commodities increased 36 percent between 2004 and $2011 .^{8}$ Real rail costs adjusted for railroad productivity increased 29 percent during the same period (see table 2). This indicates that most of the increase in rail rates was due to increased rail cost, but the increased rail rates also contributed to record rail profits. In comparison, real truck rates have increased 27 percent since 2004 (see fig. 6).

6 Surface Transportation Board, Study of Railroad Rates:1985-2007, January 2009. <http://www.stb.dot.gov/stb/industry/1985-2007RailroadRateStudy.pdf> (PDF).

7 Laurits R. Christensen Associates, Inc., A Study of Competition in the U.S. Freight Railroad Industry and Analysis of Proposals That Might Enhance Competition, November, 2008. <http://www.stb.dot.gov/stb/elibrary/CompetitionStudy.html>.

8 Association of American Railroads, Railroad Ten-Year Trends, 2001-2010, pg. 50. 
Figure 5. Rail rate index, $1985-2007$ (real revenue per ton-mile in $1985=100$ )

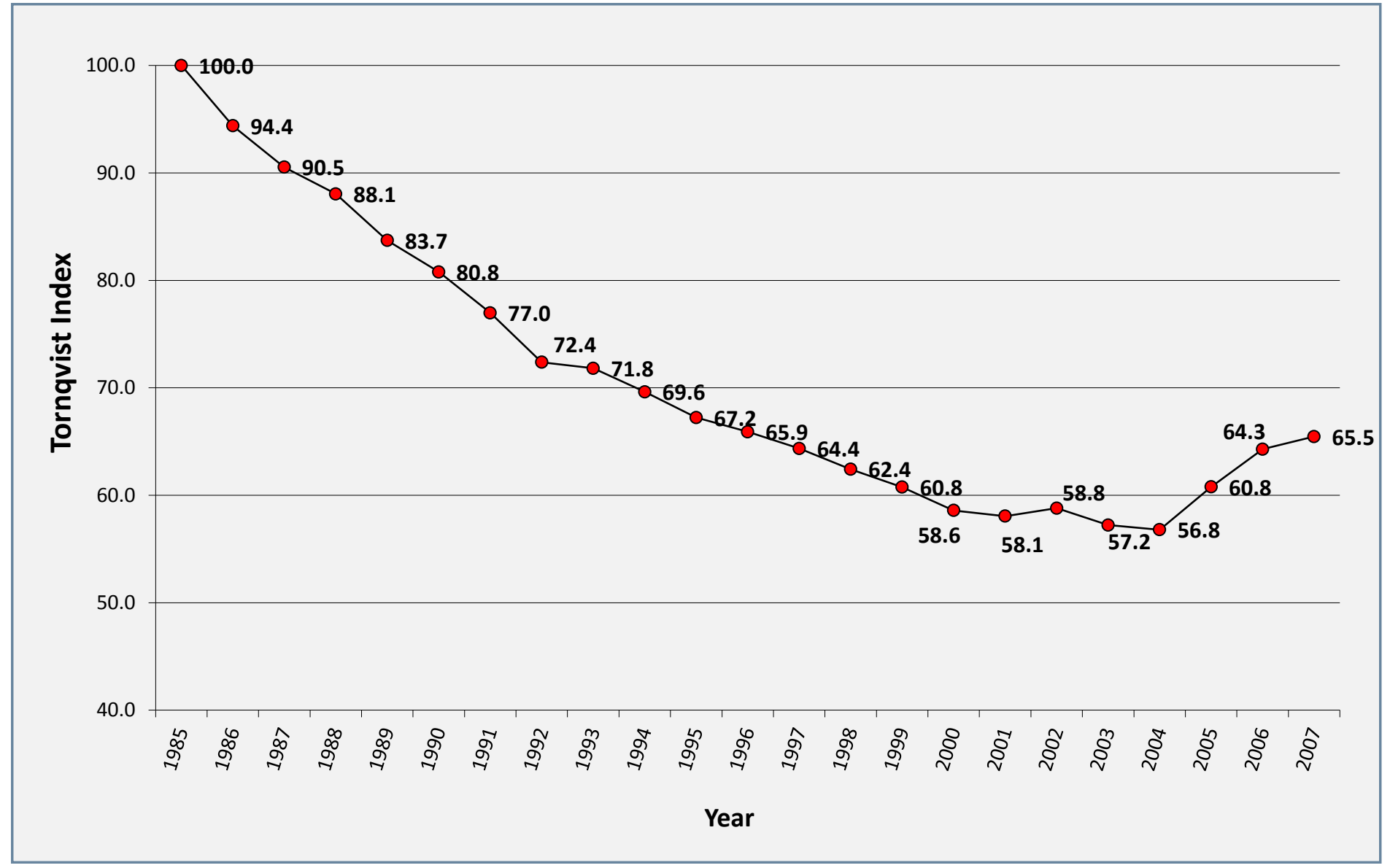

Source: Surface Transportation Board

Table 2. Annual Rail Cost Adjustment Factor (RCAF) (Adjusted for productivity) (4Q $2002=100$ for unadjusted RCAF)

\begin{tabular}{|c|c|}
\hline Year & RCAF (adjusted) \\
\hline 2003 & 0.517 \\
\hline 2004 & 0.528 \\
\hline 2005 & 0.558 \\
\hline 2006 & 0.571 \\
\hline 2007 & 0.565 \\
\hline 2008 & 0.659 \\
\hline 2009 & 0.554 \\
\hline 2010 & 0.614 \\
\hline 2011 & 0.665 \\
\hline
\end{tabular}

Source: Association of American Railroads Railroad Cost Indexes 
Figure 6. Index of for-hire truckload revenue per mile

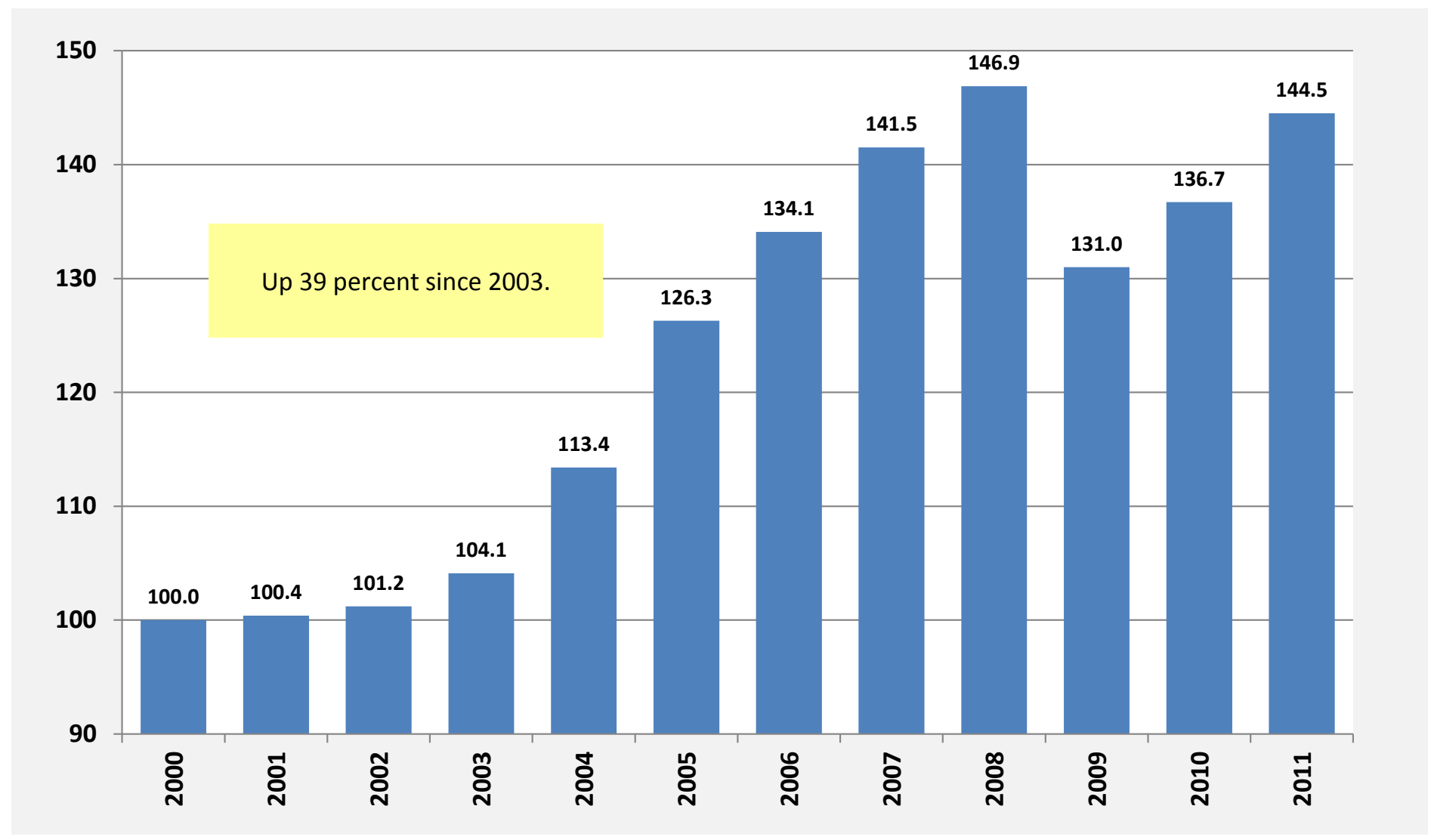

Source: American Trucking Associations, Economics \& Statistics Group, Trucking Activity Report

\section{Conclusion}

The concentration of the remaining Class I railroads has increased since 1980, the year the Staggers Rail Act was passed. The make-up of the railroad industry has changed dramatically by consolidations, mergers, and rail abandonments. Through railroad mergers, the few remaining Class I railroads have established large market shares of the rail grain transportation market, increased efficiency and market power, and reduced costs. Many of these changes have also benefitted shippers_-particularly through reductions in real rail rates-up until about 2004. Since then, however, real rail rates per ton-mile have climbed 36 percent, while real productivity-adjusted rail costs have increased 29 percent. In comparison, real truckload rates have increased 27 percent since 2004. 


\section{Page 1 photo credit:}

- @Dan Schwanz

Preferred citation:

Prater, Marvin E., Adam Sparger, and Daniel O’Neil, Jr. Railroad Concentration, Market Shares, and Rates. U.S.

Department of Agriculture, Agricultural Marketing Service, February 2014. Web. <http://dx.doi.org/10.9752/TS094.022014>

For more information, contact Marvin.Prater@ams.usda.gov.

The U.S. Department of Agriculture (USDA) prohibits discrimination against its customers. If you believe you experienced discrimination when obtaining services from USDA, participating in a USDA program, or participating in a program that receives financial assistance from USDA, you may file a complaint with USDA. Information about how to file a discrimination complaint is available from the Office of the Assistant Secretary for Civil Rights. To file a complaint of discrimination, complete, sign and mail a program discrimination complaint form, available at any USDA office location or online at www.ascr.usda.gov, or write to: USDA, Office of the Assistant Secretary for Civil Rights, 1400 Independence Avenue, S.W., Washington, D.C. 20250-9410. Or call toll free at (866) 632-9992 (voice) to obtain additional information, the appropriate office or to request documents. Individuals who are deaf, hard of hearing or have speech disabilities may contact USDA through the Federal Relay service at (800) 877-8339 or (800) 845-6136 (in Spanish). USDA is an equal opportunity provider, employer and lender. Persons with disabilities who require alternative means for communication of program information (e.g., Braille, large print, audiotape, etc.) should contact USDA's TARGET Center at (202) 720-2600 (voice and TDD). 